\title{
The Susceptibility of Strains of Mycobacterium tuberculosis to Catalase-mediated Peroxidative Killing
}

\author{
By P. S. JACKETT, V. R. ABER AND D. B. LOWRIE* \\ Medical Research Council Unit for Laboratory Studies of Tuberculosis, \\ Royal Postgraduate Medical School, DuCane Road, Hammersmith, London W12 OHS
}

(Received 3 June 1980; revised 14 July 1980)

\begin{abstract}
At low $\mathrm{pH}$ and with continuous low concentrations of hydrogen peroxide generated in situ, catalase was able to replace peroxidase in the peroxidase/hydrogen peroxide/iodide microbicidal system. The system was effective against Escherichia coli and Mycobacterium tuberculosis. Iodide could not be replaced by chloride. The system was effective in lactate buffer, but not in citrate/phosphate buffer. Strains of $M$. tuberculosis with high and low virulence were equally susceptible. The observations are discussed in the context of an involvement of host-cell catalase in a possible intracellular killing mechanism against M. tuberculosis.
\end{abstract}

\section{INTRODUCTION}

Histopathological studies indicate that the major cells involved in host resistance to Mycobacterium tuberculosis are macrophages (Lurie, 1964). Although it is probable that immunologically activated macrophages in particular can kill even virulent tubercle bacilli in vivo, this is as yet unproven. Nevertheless, normal mouse peritoneal macrophages can show transient ability to inhibit growth of virulent $M$. tuberculosis strain $\mathrm{H} 37 \mathrm{Rv}$ and kill attenuated strain H37Ra in vitro (Hart \& Armstrong, 1974). Thus, the isolated macrophage appears to have some tuberculocidal potential that might find more powerful and more sustained expression in vivo. The nature of the killing mechanisms involved is unknown. However, there are pointers to the involvement of $\mathrm{H}_{2} \mathrm{O}_{2} \cdot \mathrm{H}_{2} \mathrm{O}_{2}$ is produced by macrophages (Klebanoff \& Hamon, 1975; Rister \& Baehner, 1977; Nathan \& Root, 1977; Boxer et al., 1979), and resistance to $\mathrm{H}_{2} \mathrm{O}_{2}$ is a virulence determinant in $M$. tuberculosis (Mitchison et al., 1963; Narayanan-Nair et al., 1964). Although susceptibility to $\mathrm{H}_{2} \mathrm{O}_{2}$ correlates with low virulence in many strains, laboratory-attenuated strains retain resistance to $\mathrm{H}_{2} \mathrm{O}_{2}$ (Jackett et al., 1978 a). This implies that different antimicrobial mechanisms within the macrophage other than the direct action of $\mathrm{H}_{2} \mathrm{O}_{2}$ kill these strains. However, the possibility remains that an $\mathrm{H}_{2} \mathrm{O}_{2}$-mediated mechanism may be involved. Since their first discovery (Reiter et al., 1964; Klebanoff \& Luebke, 1965) peroxidase-mediated systems have been shown to contribute to microbial killing in polymorphonuclear leucocytes, by enhancing greatly the bactericidal power of $\mathrm{H}_{2} \mathrm{O}_{2}$ (Klebanoff \& Clark, 1978). In previous studies, strains of $M$. tuberculosis of diverse virulence in the guinea-pig were tested for their susceptibility to peroxidase $/ \mathrm{H}_{2} \mathrm{O}_{2} /$ halide systems (Jackett et al., 1978b). All strains were susceptible to such a system with iodide and, to a much lesser extent, chloride as cofactor, and no correlation with virulence was observed.

The peroxidase content of macrophages is very low relative to that of polymorphonuclear leucocytes (Biggar \& Sturgess, 1976; Lepper \& Hart, 1976; Ogawa et al., 1978). However, Klebanoff $(1969,1970)$ showed that catalase can replace peroxidase in the killing system 
under certain conditions in vitro. Activity against a wide variety of micro-organisms was shown but the studies did not include $M$. tuberculosis.

Normally, catalase is found in the peroxisomes and cytosol (Lowrie et al., 1977; Davies et al., 1979), but transfer of macrophage catalase into the phagocytic vacuole during phagocytosis has been reported (Stossel et al., 1972; Eguchi et al., 1979).

If strains of $M$. tuberculosis could be shown to be susceptible to catalase-mediated systems in vitro, and if high susceptibility was correlated with low virulence, this might imply the involvement of the systems in vivo. The strains of $M$. tuberculosis previously studied (Jackett et al., $1978 a, b$ ) were therefore examined for their susceptibility to catalase-mediated systems.

\section{METHODS}

Organisms. A strain of Escherichia coli B was used for preliminary experiments. Six strains of Mycobacterium tuberculosis were used. The properties of these strains have been reported previously (Jackett et al., 1978a). Two strains (I2646 and 79499) were of high virulence and four (H37Ra, B1453, 79112 and the isoniazid-resistant variant 79112R) of low virulence in the guinea-pig. Both strains of high virulence were resistant to $\mathrm{H}_{2} \mathrm{O}_{2}$; of the strains of low virulence, the laboratory-attenuated strain $\mathrm{H} 37 \mathrm{Ra}$ was resistant to $\mathrm{H}_{2} \mathrm{O}_{2}$ and the other three were sensitive to $\mathrm{H}_{2} \mathrm{O}_{2}$.

Growth conditions. Escherichia coli B was grown at $37^{\circ} \mathrm{C}$ in nutrient broth (Oxoid no. 2) and used after $3 \mathrm{~h}$ incubation, i.e. at the late-exponential phase of growth. Mycobacterium tuberculosis was grown at $37^{\circ} \mathrm{C}$ in catalase-free liquid medium 7H9 (Jackett et al., 1978a) and used for tests after 4 or 7 d, i.e. at the midand late-exponential phases of growth, respectively (Jackett $e t a l ., 1978 b$ ).

Catalase-mediated killing tests. The test system consisted of three components: (i) $\mathrm{H}_{2} \mathrm{O}_{2}$ generated in situ by glucose oxidase-catalysed oxidation of glucose, (ii) catalase, and (iii) a halide which was either iodide or chloride. Each experiment included comprehensive controls where single and multiple components were omitted. Two buffers were compared: a buffer composed of $50 \mathrm{~mm}$-citric acid and $50 \mathrm{~mm}$-sodium phosphate (citrate/phosphate), and $25 \mathrm{~mm}$-lactate buffer, both at $\mathrm{pH} 5 \cdot 0$. Klebanoff (1970) measured the peroxidative killing of E. coli in $50 \mathrm{~mm}$-lactate at $\mathrm{pH} 4.5$ to 5.0 , but this proved to be toxic for $M$. tuberculosis. The details of the test method have been described previously (Jackett $e t a l ., 1978 b$ ) with the exception that catalase $(1000$ or $3000 \mathrm{U})$ was now substituted for peroxidase. Briefly, bacteria suspended in test mixtures to a final volume of $1 \mathrm{ml}$ were incubated for $1 \mathrm{~h}$ in a $37^{\circ} \mathrm{C}$ water-bath. At the end of the incubation period $100 \mu \mathrm{l}$ samples were removed, diluted in $0.01 \%(\mathrm{w} / \mathrm{v})$ bovine serum albumin fraction V (Armour Pharmaceuticals, Eastbourne, Sussex) and colony-forming units (c.f.u.) were assessed on blood-agar base (Oxoid) or 7H11 agar (Jackett et al., 1978a) for E. coli and $M$. tuberculosis, respectively. The number of c.f.u. in a test mixture was expressed as a percentage of the number of c.f.u. in control tubes containing glucose and buffer only. The statistical significance of differences in percentage survival in different test conditions was assessed by analysis of variance.

Test reagents. Glucose oxidase (type V) containing $200 \mathrm{U}$ (mg protein) ${ }^{-1}$ was obtained from Sigma. Catalase was obtained from Boehringer [beef liver, $50 \mathrm{U}$ (mg protein) ${ }^{-1}: 1$ unit decomposes $1 \mu \mathrm{mol} \mathrm{H}_{2} \mathrm{O}_{2} \mathrm{~min}^{-1}$ at $\mathrm{pH} 7.0$ and $25^{\circ} \mathrm{Cl}$. All other reagents were analytical grade (BDH).

\section{RESULTS}

In experiments where bacterial killing was demonstrated with the combination of glucose, glucose oxidase, catalase and halide, omission of one or more of the components resulted in loss of the bactericidal effect. In most instances, for brevity, these controls have been omitted from the tables.

\section{Killing of E. coli}

Experiments with $E$. coli confirmed that a catalase-mediated peroxidative killing system was effective (Table 1). However, the bactericidal effect was only evident in lactate buffer. In addition, the system was bactericidal only in the presence of iodide. No killing was observed when iodide was replaced by chloride. 


\section{Table 1. Susceptibility of E. coli $B$ to catalase-mediated killing}

Bacterial suspensions $\left(2 \times 10^{5}\right.$ bacteria $\left.\mathrm{ml}^{-1}\right)$ were incubated with the various additives and glucose $\left(10 \mathrm{~mm}\right.$ ) for $1 \mathrm{~h}$ at $37^{\circ} \mathrm{C}$, at $\mathrm{pH} \mathrm{5 \cdot 0}$. Tests and controls (organisms in glucose buffer only) were incubated in duplicate in two experiments for each buffer. Survival in test conditions is expressed as a percentage of the survival in controls, i.e. $100 \times$ (c.f.u. $\mathrm{ml}^{-1}$ in test conditions)/(c.f.u. $\mathrm{ml}^{-1}$ in buffer control); each value is the geometric mean of four observations.

\begin{tabular}{|c|c|c|c|c|}
\hline \multicolumn{3}{|c|}{ Test conditions } & \multicolumn{2}{|c|}{ Mean percentage survival } \\
\hline $\begin{array}{l}\text { Glucose oxidase* } \\
\qquad\left(\mathrm{U} \mathrm{ml}^{-1}\right)\end{array}$ & $\begin{array}{l}\text { Catalase } \\
\left(\mathrm{U} \mathrm{ml}^{-1}\right)\end{array}$ & $\begin{array}{l}\text { Cofactor } \\
\text { (mM) }\end{array}$ & $\begin{array}{c}\text { Citrate/phosphate } \\
\text { buffer }(50 \mathrm{~mm})\end{array}$ & $\begin{array}{l}\text { Lactate buffer } \\
\quad(25 \mathrm{mM})\end{array}$ \\
\hline $0 \cdot 02 / 0 \cdot 005$ & - & 一 & 113 & 38 \\
\hline $0.02 / 0.005$ & 1000 & - & 92 & 100 \\
\hline $0.02 / 0.005$ & - & $\mathrm{KI}(0 \cdot 1)$ & 100 & 42 \\
\hline $0.02 / 0.005$ & - & $\mathrm{KCl}(100)$ & 107 & 40 \\
\hline $0.02 / 0.005$ & 1000 & $\mathrm{KI}(0 \cdot 1)$ & 86 & $<0.1$ \\
\hline $0.02 / 0.005$ & 1000 & $\mathrm{KCl}(100)$ & 92 & 113 \\
\hline $0.005 / 0.005$ & $\mathrm{LP}, 200 \dagger$ & $\mathrm{KI}(0.01)$ & $<0 \cdot 1$ & $<0 \cdot 1$ \\
\hline
\end{tabular}

Table 2. Susceptibility of $M$. tuberculosis to catalase-mediated killing in lactate buffer

Experimental conditions and methods of estimation of survival are as in Table 1.

\begin{tabular}{|c|c|c|c|c|c|c|c|c|}
\hline \multicolumn{3}{|c|}{ Test conditions } & \multicolumn{6}{|c|}{ Mean percentage survival } \\
\hline \multirow{2}{*}{$\begin{array}{c}\text { Glucose } \\
\text { oxidase } \\
\left(\mathrm{U} \mathrm{ml} \mathrm{ml}^{-1}\right)\end{array}$} & \multirow[b]{2}{*}{$\begin{array}{l}\text { Catalase } \\
\left(\mathrm{U} \mathrm{ml}^{-1}\right)\end{array}$} & \multirow[b]{2}{*}{$\begin{array}{l}\text { Cofactor } \\
\text { (mM) }\end{array}$} & \multicolumn{6}{|c|}{ Strains of $M$. tuberculosis } \\
\hline & & & $\begin{array}{c}\mathrm{I} 2646 \\
(\mathrm{H})^{*}\end{array}$ & $\begin{array}{c}79499 \\
(\mathrm{H})\end{array}$ & $\begin{array}{l}\text { H37Ra } \\
\text { (L) }\end{array}$ & $\begin{array}{c}\text { B1453 } \\
\text { (L) }\end{array}$ & $\begin{array}{c}79112 \\
(\mathrm{~L})\end{array}$ & $\begin{array}{c}79112 \mathrm{R} \\
\text { (L) }\end{array}$ \\
\hline $\begin{array}{l}0.02 \\
0.28\end{array}$ & - & - & $\begin{array}{l}96 \\
35\end{array}$ & $\begin{array}{l}88 \\
38\end{array}$ & $\begin{array}{l}96 \\
94\end{array}$ & $\begin{array}{l}88 \\
70\end{array}$ & $\begin{array}{l}84 \\
56\end{array}$ & $\begin{array}{l}81 \\
44\end{array}$ \\
\hline $\begin{array}{l}\overline{0.02} \\
0 \cdot 28\end{array}$ & $\begin{array}{l}- \\
3000 \\
3000\end{array}$ & $\begin{array}{l}\mathrm{KCl}(100) \\
\mathrm{KCl}(100) \\
\mathrm{KCl}(100)\end{array}$ & $\begin{array}{l}88 \\
69 \\
67\end{array}$ & $\begin{array}{l}83 \\
63 \\
36\end{array}$ & $\begin{array}{l}65 \\
57 \\
72\end{array}$ & $\begin{array}{l}78 \\
84 \\
87\end{array}$ & $\begin{array}{l}39 \\
42 \\
50\end{array}$ & $\begin{array}{l}55 \\
36 \\
43\end{array}$ \\
\hline $\begin{array}{l}0.02 \\
0.28\end{array}$ & $\begin{array}{l}3000 \\
3000\end{array}$ & $\begin{array}{l}\mathrm{KI}(0.01) \\
\mathrm{KI}(0.01)\end{array}$ & $\begin{array}{l}63 \\
38\end{array}$ & $\begin{array}{l}18 \\
15\end{array}$ & $\begin{array}{l}28 \\
59\end{array}$ & $\begin{array}{l}68 \\
73\end{array}$ & $\begin{array}{l}58 \\
55\end{array}$ & $\begin{array}{l}25 \\
37\end{array}$ \\
\hline $\begin{array}{l}0.02 \\
0.28\end{array}$ & $\begin{array}{l}3000 \\
3000\end{array}$ & $\begin{array}{l}\mathrm{KI}(0 \cdot 1) \\
\mathrm{KI}(0 \cdot 1)\end{array}$ & \multicolumn{6}{|c|}{ No survival } \\
\hline 0.02 & $\mathrm{LP}, 200 \dagger$ & $\mathrm{KI}(0.01)$ & \multicolumn{6}{|c|}{ No survival } \\
\hline
\end{tabular}

\section{Killing of $M$. tuberculosis}

Phase of culture. Overall, there was no difference in the susceptibilities of the strains in mid-exponential ( $4 \mathrm{~d}$ ) or late-exponential ( $7 \mathrm{~d}$ ) phases of growth. Therefore, the results for the $4 \mathrm{~d}$ cultures (mid-exponential phase) only are presented.

Susceptibility with iodide as cofactor. The results closely paralleled those with $E$. coli, but increased concentrations of enzymes were needed for killing (Table 2). There was no killing in citrate/phosphate buffer (results not shown). In lactate buffer, $100 \mu \mathrm{M}$-iodide was more effective than $10 \mu \mathrm{M}$-iodide. At the lower concentration of iodide, there was no significant difference between the effects of glucose oxidase at 0.02 or $0.28 \mathrm{U} \mathrm{ml}^{-1}$. However, at 100 $\mu \mathrm{M}$-iodide, the considerable bactericidal effect was greater with the lower concentration of glucose oxidase. Other results (not shown) indicated that under any of the conditions tested $1000 \mathrm{U}$ catalase $\mathrm{ml}^{-1}$ was less effective than $3000 \mathrm{U} \mathrm{ml}^{-1}$. Between $M$. tuberculosis strains minor differences in susceptibility did not correlate with differences in virulence. 
Susceptibility with chloride as cofactor. No killing was seen with chloride. Although there was some reduction in numbers of c.f.u. with the complete catalase $/ \mathrm{H}_{2} \mathrm{O}_{2} /$ chloride system, this effect was no greater than that of glucose oxidase and chloride alone. Indeed, with the $7 \mathrm{~d}$ cultures, addition of catalase appeared antagonistic to killing, and protected the organisms.

\section{DISCUSSION}

The reports that catalase can substitute for peroxidase in microbicidal reactions in vitro against a variety of micro-organisms (Klebanoff, 1969, 1970) have now been confirmed with E. coli and extended to $M$. tuberculosis.

Although all of the strains of $M$. tuberculosis studied here were killed by a catalasemediated system and there was some difference in survival between the strains $(P<0 \cdot 01)$, there was no correlation between low virulence and high susceptibility to catalase-mediated killing systems.

The catalase-mediated antibacterial activity was only observed in lactate buffer. The mechanism by which lactate supported the killing of bacteria by catalase, whereas citrate/ phosphate did not, is unknown. However, it has been known for a long time that citrate ions can inhibit the activity of some enzymes and that lactic acid is toxic to a variety of bacteria at low $\mathrm{pH}$ (Dubos, 1955a). Although the concentration of lactate used here was selected as being the highest at which no lactate toxicity was detectable with any of the strains of $M$. tuberculosis during $90 \mathrm{~min}$ at $37^{\circ} \mathrm{C}$, it is possible that this concentration nevertheless produced sub-lethal damage that facilitated susceptibility to the catalase system. Lactate also enhanced the bactericidal power of the in situ-generated $\mathrm{H}_{2} \mathrm{O}_{2}$ in the absence of halide and catalase. Both lactate and $\mathrm{H}_{2} \mathrm{O}_{2}$ are produced in increased amounts during phagocytosis (Oren et al., 1963; Ouchi et al., 1965; Gee et al., 1970, 1971; Stossel et al., 1972; Drath et al., 1978).

That catalase can function peroxidatively has been known for many years. The essential condition for such action is the presence of a low steady state concentration of $\mathrm{H}_{2} \mathrm{O}_{2}$ relative to the catalase concentration and peroxidative activity is further favoured by low $\mathrm{pH}$ (Klebanoff, 1969). Preliminary results (which have not been given here) showing that peroxide added directly was ineffective, together with the observations that decreasing the rate of $\mathrm{H}_{2} \mathrm{O}_{2}$ generation by lowering the glucose oxidase concentration enhanced killing of tubercle bacilli (Table 2), are consistent with the involvement of a peroxidative activity of catalase. The $M$. tuberculosis strains tested were evidently more resistant to the toxic products of the reaction than was $E$. coli since higher concentrations of reactants were needed to kill $M$. tuberculosis. Suitable conditions of low $\mathrm{pH}$ and continuous $\mathrm{H}_{2} \mathrm{O}_{2}$ evolution may be found within the phagocytic vacuoles of certain types of macrophages (Klebanoff \& Hamon, 1975).

Abundant catalase has been found in pulmonary alveolar macrophages of rabbit (Gee et al., 1970; Stossel et al., 1972; Lowrie et al., 1977) and rat (Davies et al., 1979) and peritoneal exudate macrophages of guinea-pig (Simmons \& Karnovsky, 1973). The enzyme is about equally distributed between non-lysosomal granules (presumptive peroxisomes) and cytosol in the rabbit and rat cells (Stossel et al., 1972; Davies et al., 1979). Mouse peritoneal macrophages contain less than one-tenth as much activity (Simmons \& Karnovsky, 1973) and this is virtually confined to non-lysosomal granules (D. B. Lowrie, unpublished results). Peroxidative activity, which was probably due to catalase rather than myeloperoxidase, has been demonstrated in granule fractions of the pulmonary macrophage of the rabbit. The activity was diminished by the catalase inhibitor 3-amino-1,2,4-triazole, and the granule fractions showed bactericidal activity against $E$. coli in the presence of a $\mathrm{H}_{2} \mathrm{O}_{2}$-generating system and iodide in lactate buffer at $\mathrm{pH} 4.5$ (Paul et al., 1973). If a catalase-dependent system contributes to killing in the phagocytic vacuoles of intact cells then catalase translocation from either cytosol or granules into vacuoles must occur. There is evidence that 
catalase enters phagocytic vacuoles which contain oil droplets in rabbit pulmonary macrophages (Stossel et al., 1972) or which contain latex particles in rat peritoneal macrophages (Eguchi et al., 1979), but no evidence of such transfer was found in rat Kupffer cells containing latex (Fahimi et al., 1976). Evidence for transfer into vacuoles containing tubercle bacilli is clearly needed, particularly as live tubercle bacilli can inhibit fusion of their phagocytic vacuoles with lysosomes (Hart et al., 1972; Lowrie et al., 1979).

There is abundant chloride in macrophages (Klebanoff, 1975; Castranova et al., 1979), and presumably also in phagocytic vauoles, but we have confirmed that catalase-dependent killing does not occur with chloride as the cofactor in place of iodide. Although iodide is effective at concentrations as low as $1 \mu \mathrm{M}$ in peroxidase-mediated killing of $M$. tuberculosis (Jackett et al., 1978b), this iodide concentration was ineffective with catalase. The concentration required was at least tenfold higher, with some effect seen at $10 \mu \mathrm{M}$. It is not known if this concentration of iodide is reached within the macrophage, but treatment with iodine-containing hormones can enhance host resistance to tuberculosis. This has been seen in rabbits (Lurie, 1964), mice (Dubos, 1955b) and guinea-pigs (Bloch, 1963), and macrophages from triiodothyronine-treated guinea-pigs had enhanced ability to suppress growth of M. tuberculosis in vitro (Hsu \& Kapral, 1960). However, administration of thyroid hormones in amounts sufficient to inhibit weight-gain had adverse effects on host resistance in mice (Dubos, 1955b) and no beneficial effects in man (Nodine et al., 1959). Whether the beneficial effects seen at lower doses in animals are a consequence of increased iodide availability for catalase-dependent killing in infected macrophages has not been established.

\section{REFERENCES}

Biggar, W. D. \& Sturgess, J. M. (1976). Peroxidase activity of alveolar macrophages. Laboratory Investigation 34, 31-42.

BLoch, R. G. (1963). The effect of hyperthyroidism on tuberculosis in the guinea-pig: a possible approach to experimental sarcoidosis. American Review of Respiratory Disease 87, 525-528.

Boxer, L. A., Ismail, G., Allen, J. M. \& Baehner, R. L. (1979). Oxidative metabolic responses of rabbit pulmonary alveolar macrophages. Blood 53, 486-491.

Castranova, V., Bowman, L. \& Miles, P. R. (1979). Transmembrane potential and ionic content of rat alveolar macrophages. Journal of Cellular Physiology 101, 471-480.

Davies, P., Drath, D. B., Engel, E. E. \& Huber, G. L. (1979). The localisation of catalase in the pulmonary alveolar macrophage. Laboratory Investigation 40, 221-226.

Drath, D. B., Harper, A., Gharibian, J., Karnovsky, M. L. \& Huber, G. L. (1978). The effect of tobacco smoke on the metabolism and function of rat alveolar macrophages. Journal of Cellular Physiology 95, 105-114.

Dubos, R.J. (1955a). The micro-environment of inflammation or Metchnikoff revisited. Lancet 269, 1-5.

DuBos, R. J. (1955 $b$ ). Effect of metabolic factors on the susceptibility of albino mice to experimental tuberculosis. Journal of Experimental Medicine 101, 59-84.

Eguchi, M., SanNes, P. L. \& SpICer, S. S. (1979). Peroxisomes of rat peritoneal macrophages during phagocytosis. American Journal of Pathology 95, 281-288.
Fahimi, H. D., Gray, B. A. \& Herzog, V. K. (1976). Cytochemical localization of catalase and peroxidase in sinusoidal cells of rat liver. Laboratory Investigation 34, 192-201.

Gee, J. B. L., Vassallo, C. L., Bell, P., Kaskin, J., BASFORD, R. E. \& FIELD, J. (1970). Catalasedependent peroxidative metabolism in the alveolar macrophage during phagocytosis. Journal of Clinical Investigation 49, 1280-1287.

Gee, J. B. L., Vassallo, C. L., Vogt, M. T., Thomas, C. \& Basford, R. E. (1971). Peroxidative metabolism in alveolar macrophages. Archives of Internal Medicine 127, 1046-1049.

Hart, P. D'A. \& Armstrong, J. A. (1974). Strain virulence and the lysosomal response in macrophages infected with Mycobacterium tuberculosis. Infection and Immunity 10, 742-746.

Hart, P. D'A., Armstrong, J. A., Brown, C. A. \& DRAPER, P. (1972). Ultrastructural study of the behaviour of macrophages toward parasitic mycobacteria. Infection and Immunity 5, 803-807.

Hsu, H.-S. \& Kapral, F. A. (1960). The suppressed multiplication of tubercle bacilli within macrophages derived from triiodothyronine-treated guinea-pigs. American Review of Respiratory Disease 81, 881-887.

JACkett, P. S., ABer, V. R. \& Lowrie, D. B. $(1978 a)$. Virulence and resistance to superoxide, low $\mathrm{pH}$ and hydrogen peroxide among strains of Mycobacterium tuberculosis. Journal of General Microbiology 104, 37-45.

JACKeTt, P. S., Aber, V. R. \& Lowrie, D. B. (1978b). Virulence of Mycobacterium tuberculosis and susceptibility to peroxidative killing systems. Journal of General Microbiology 107, 273-278. 
KLebanofF, S. J. (1969). Antimicrobial activity of catalase at acid $\mathrm{pH}$. Proceedings of the Society for Experimental Biology and Medicine 132, 571-574.

KLEBANOFF, S. J. (1970). Myeloperoxidase-mediated antimicrobial systems and their role in leukocyte function. In Biochemistry of the Phagocytic Process, pp. 89-110. Edited by G. J. Schultz. Amsterdam: North Holland.

KLebanoff, S. J. (1975). Antimicrobial mechanisms in neutrophilic polymorphonuclear leukocytes. Seminars in Hematology 12, 117-142.

Klebanoff, S. J. \& Clark, R. A. (1978). The Neutrophil: Function and Clinical Disorders. Amsterdam: Elsevier/North-Holland.

Klebanoff, S. J. \& Hamon, C. B. (1975). Antimicrobial systems of mononuclear phagocytes. In Mononuclear Phagocytes in Immunity, Infection and Pathology, pp. 507-529. Edited by R. van Furth. Oxford: Blackwell Scientific Publications.

Klebanoff, S. J. \& LuebKe, R. G. (1965). The antilactobacillus system of saliva. Role of salivary peroxidase. Proceedings of the Society for Experimental Biology and Medicine 118, 483-486.

Lepper, A. W. D. \& HarT, P. D'A. (1976). Peroxidase staining in elicited and nonelicited mononuclear peritoneal cells from BCG-sensitized and nonsensitized mice. Infection and Immunity 14, 522-526.

Lowrie, D. B., Andrew, P. W. \& Peters, T. J. (1977). Analytical fractionation of subcellular organelles from the pulmonary alveolar macrophages of normal and BCG-vaccinated rabbits. Biochemical Society Transactions 5, 1458-1460.

Lowrie, D. B., ABER, V. R. \& JACKeTt, P. S. (1979). Phagosome-lysosome fusion and cyclic adenosine $3^{\prime}: 5^{\prime}$-monophosphate in macrophages infected with Mycobacterium microti, Mycobacterium bovis BCG or Mycobacterium lepraemurium. Journal of General Microbiology 110, 431-441.

LURIE, M. B. (1964). Resistance to Tuberculosis: Experimental Studies in Native and Acquired Defensive Mechanisms. Cambridge, Mass.: Harvard University Press.

Mitchison, D. A., Selkon, J. B. \& Lloyd, J. (1963). Virulence in the guinea-pig, susceptibility to hydrogen peroxide, and catalase activity of isoniazid-sensitive tubercle bacilli from South Indian and British patients. Journal of Pathology and Bacteriology 86, 377-386.

Narayanan-NaIR, C., Mackay-Scollay, E. M., Ramachandran, K., Selkon, J. B., Tripathy,
S. P., Mitchison, D. A. \& Dickinson, J. M. (1964). Virulence in the guinea-pig and susceptibility to hydrogen peroxide of isoniazid-sensitive tubercle bacilli from South Indian patients. Tubercle 45, 345-353.

Nathan, C. F. \& Root, R. K. (1977). Hydrogen peroxide release from mouse peritoneal macrophages. Dependence on sequential activation and triggering. Journal of Experimental Medicine 146, 1648-1662.

Nodine, J. H., Yoshizawa, H., Weiss, W., Stein, S. C., Guth, R. \& Tummillo, M. (1959). The effect of $\mathbf{L}$-triiodothyronine in pulmonary tuberculosis: a pilot study. American Journal of Medical Sciences 237, 27-41.

Ogawa, T., Koerten, H. K. \& Daems, W. Th. (1978). Peroxidatic activity in monocytes and tissue macrophages of mice. Cell and Tissue Research 188, 361-373.

Oren, R., Farnham, A. E., Saito, K., Milofsky, E. \& KaRnovsKY, M. L. (1963). Metabolic patterns in three types of phagocytosing cells. Journal of Cell Biology 17, 487-501.

Ouchi, E., Selvaraj, R. J. \& Sbarra, A. J. (1965). The biochemical activities of rabbit alveolar macrophages during phagocytosis. Experimental Cell Research 40, 456-468.

Paul, B. B., Strauss, R. R., SelvaraJ, R. J. \& Sbarra, A. J. (1973). Peroxidase-mediated antimicrobial activities of alveolar macrophage granules. Science 181, 849-850.

Reiter, B., Pickering, A. \& Oram, J. D. (1964). An inhibitory system - lactoperoxidase, thiocyanate, peroxide - in raw milk. In 4th International Symposium on Food Microbiology, pp. 297-305. Edited by N. Molin. Stockholm: Almqvist and Wilsell.

RISTER, M. \& BAEHNER, R. L. (1977). Effect of hyperoxia on superoxide anion and hydrogen peroxide production of polymorphonuclear leucocytes and alveolar macrophages. British Journal of Haematology 36, 241-248.

Simmons, S. R. \& Karnovsky, M. L. (1973). Iodinating ability of various leukocytes and their bactericidal activity. Journal of Experimental Medicine 138, 44-63.

Stossel, T. P., Mason, R. J., Pollard, T. D. \& VAughan, M. (1972). Isolation and properties of phagocytic vesicles. II. Alveolar macrophages. Journal of Clinical Investigation 51, 604-614. 